\title{
North Carolina Library Association 2009 Election Slate
}

\section{Director}

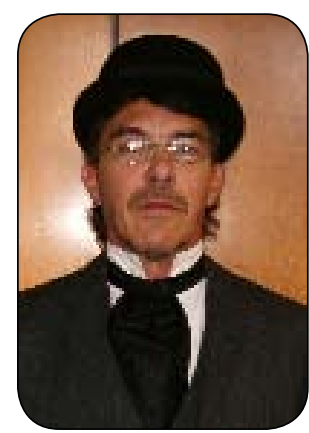

\section{Allen Mosteller}

Reference/Public Services Librarian

Cleveland Community College

Shelby, North Carolina

\section{Education}

MLIS, University of North Carolina

Greensboro

BS, Management Information Systems

Gardner-Webb University

\section{Library Positions}

ClevelandCommunityCollege, Reference/PublicServicesLibrarian UNCG, Graduate Assistant, School of Library and Information Studies

\section{North Carolina Library Association \\ 2005 NCLA Leadership Institute}

Resources and Technical Services (RTSS) Section, Secretary-

Treasurer, 2005-07

Business Librarianship in North Carolina (BLINC) Section

Community and Junior Colleges Section Director, 2007-09

NCLA 2007 Conference Exhibits Committee

\section{Platform Statement}

My motivating goal is to provide a forum and support for the free exchange of ideas and support of intellectual freedom and information literacy for all library patrons. My vocation and priority is to serve others, and my mission is to provide resources and guidance for individuals to be able to read, write, and draw conclusions. My potential to make a contribution derives from working in the community college system which has provided me the foundation to develop effective leadership abilities. My library is the synthesis of both academic and public serving the student, faculty, and community population as a learning place, information repository and access point, as well as a community center. Dealing with the diverse nature of our service base has helped to prepare me to deal with all levels and aspects of the library's role in the teaching and service process. Working with traditional and nontraditional students as well as community patrons, faculty, and staff has enabled me to take part in the instruction and learning process at all levels. I am focused on providing students, faculty, and the community with library resources that expand and enhance their everyday lives, professions, and general skills. I have experience in areas of collaboration and innovative uses of technology in providing reference and library instruction. I am currently in the process of completing a graduate certificate at Appalachian State University in web based course design, delivery, and instruction for distance education. I am a strong advocate for using technology to deliver information and instruction online through the library and am determined to teach patrons that the library can never be replaced by the internet. The value of being an NCLA member has provided me the opportunity to work with professionals throughout the library community playing a vital role in my development as a professional librarian. It would be both a great honor and pleasure to serve my fellow librarians in the position of Director.

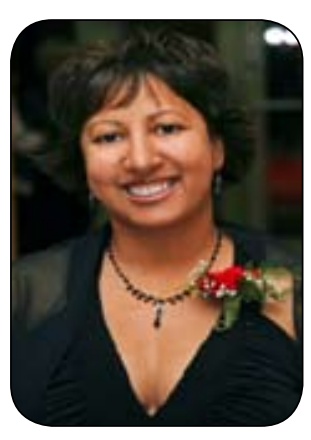

\section{Tammy Baggett}

Assistant Library Director New Hanover County Public Library Wilmington, North Carolina

\section{Education}

MLS, North Carolina Central University

BA, Speech Communication/Public

Relations, University of North Carolina at Wilmington

\section{Library Positions}

Assistant Library Director, New Hanover County Public Library Senior Library Manager, Public Library of Charlotte \& Mecklenburg County

Assistant Regional Branch Manager/Children's Librarian, Atlanta Fulton Public Library

Branch Manager, Forsyth County Public Library

Library Associate, Durham County Pubic Library

Library Assistant, New Hanover County Public Library

\section{Platform Statement}

The library world is constantly experiencing change and the North Carolina Library Association is a valuable forum to discuss library issues and the profession as a whole. My range of library experience allows me to serve as a voice for various facets of the profession including Children Services, Young Adult Services, Adult Services and Outreach. I'm dedicated to promoting libraries as a community center that provides meaningful experiences to all users throughout North Carolina. Often when people relocate they look for areas with great schools and great libraries. North Carolina stimulates the economy by offering just that ----- great libraries. One thing that makes libraries so great is being the one place that's for everyone. Lady Bird Johnson says it all, “....the only entrance requirement (to libraries) is interest. "“

I also have a strong commitment in promoting diversity, mentoring new librarians, and increasing interest in the profession. While working in the field of librarianship is both rewarding and challenging we each have a commitment to share our stories and to create an atmosphere that stimulates the mind, and compels new 
leaders and keepers of information to the profession. NCLA, along with great mentors have helped me grow in the profession. I take pride in being a role model for the profession and look forward to the opportunity to serve as a voice for libraries through the NCLA Executive Board. I hope my involvement will impact the profession and create a "buzz" about librarianship.

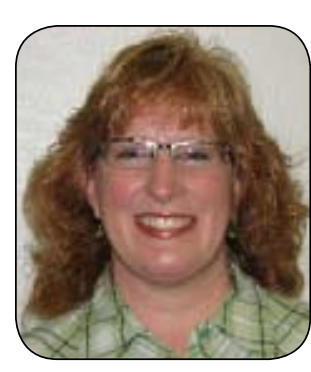

\section{Elizabeth J. Skinner}

Central Library Public Services Manager

Forsyth County Public Library

Winston-Salem, NC

\section{Education}

MLS, Florida State University

H.W. Wilson Scholarship

BA, English, Florida State University

\section{Library/Related Positions}

Public Services Manager, Central Library, FCPL

Chair, On the Same Page/Big Read, 2004-2009

Project Management Team, Digital Forsyth, 2006-2009

Branch Manager, Southside Branch, FCPL

Branch Manager, Walkertown Branch, FCPL

Reference Librarian, FCPL

\section{North Carolina Library Association}

Co-presenter: "Extreme Makeover-Central Library" North

Carolina Library Association Biennial Conference 2005

Co-Editor, North Carolina Libraries, Spring 2004 Issue, Vol. 62,

No. 1

NCLA Commission on the Future of Libraries and the Book, 2002-2004

NCLA Leadership Institute, 1998

Young Adult Committee, Public Library Section, North Carolina Library Association, 1988-1992

\section{Platform Statement}

In these tough economic times, as individuals and communities struggle, libraries of all types are as busy and vital as ever. U.S. News \& World Report has ranked Librarian among "The 30 Best Careers for 2009" (December 11, 2008). Librarians understand the vital role they play, but we must never be complacent. In addition to maintaining the excellence of our libraries and library services, we are charged to advocate relentlessly for libraries to the stakeholders and citizens we serve.

Libraries continue to reinvent their services and embrace new technologies while maintaining the core services customers expect. Positive leadership and the mentoring of new professionals are key to the continued success of librarianship and NCLA. Without excellent professional and paraprofessional staff, libraries will not thrive. NCLA must continue to offer relevant training and support for library staff. My twenty-three years in public libraries and my collaborative work with academic, special and school librarians will enable me to be sensitive to the interests of all types of libraries.

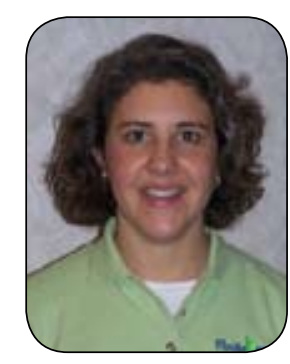

\section{Deanna Guido}

Division Manager of Educational Support

Services, Braswell Memorial Library

\section{Education}

MSLS, The Catholic University of America

BA, Music, State University of NY at Geneseo

\section{Library Experience}

Division Manager of Educational Support Services, Braswell Memorial Library

Librarian, Edgecombe Community College

Youth Services/Reference Librarian, Edgecombe County Memorial Library

Media Coordinator, Edgecombe County Pubic Schools

\section{Platform Statement}

The participants of the most recent NCLA Leadership Institute were encouraged to "show up, speak up, and stand up." When I received the call nominating me to serve on the NCLA Executive Board, I knew it was an opportunity to stand up for NC libraries and librarians. My experience has taken me from the school system to the public library to the community college and back to the public library. These rich and varied experiences give me an insight into issues faced by each type of library as well as an overview of how different types of libraries can work cooperatively.

My goal, as an executive board member, is to work collaboratively with the other members of the board to further the purpose of NCLA: "to promote libraries, library and information services, librarianship, intellectual freedom and literacy."We, as librarians, are called to be servant leaders in our communities as well as in the library community. Thank you for the opportunity to serve.

\section{Vice-President/President-Elect}

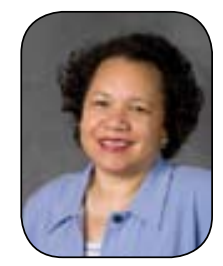

\author{
Wanda K. Brown \\ Associate Director \\ Z. Smith Reynolds Library \\ Wake Forest University \\ Winston Salem, NC
}

Education

MLS, University of North Carolina, Greensboro

BA, English, Winston Salem State University

\section{Library Positions}

Z. Smith Reynolds Library, Wake Forest University:

Associate Director

Team Leader for Technical and Access Services

Team Leader for Technical Services

Head of Cataloging

Assistant Head of Cataloging

Catalog Librarian

Library Technical Assistant 


\section{North Carolina Library Association}

Library Administration and Management Section, current Chair

Finance Committee, current Chair

2005 Biennial Conference, Local Arrangements Chair

REMCO, past Executive Board member

Treasurer, 1991-1998

College and University College Section, past Executive Board member

\section{Platform Statement}

It is an extreme honor to be nominated for the position of President of the nation's premier state library association. I hope to continue NCLA's history of strong and relevant leadership. I have displayed an enthusiastic commitment to service as a librarian and in the North Carolina Library Association for the past two decades. Because of my many years of active board membership, I know the organization well, including the administrative office, budget and finance, conference planning and especially the general membership, because the members are the organization's strength. My recent experience as Vice-President and President of the Black Caucus of the American Library Association and my experience as treasurer of both NCLA and BCALA have prepared me well as libraries face two obvious leadership challenges: the financial problems that face all of our libraries; and the need to recruit and hire good librarians, starting with our young people. My valuable experience working with different librarians nationwide will help in these efforts for recruitment, development and retention. Exploring new collaborative partnerships and enhancing existing ones will provide our libraries with an additional resource in weathering this economic challenge. For these reasons, along with the time-honored respect I have for intellectual freedom and for continuing excellence in North Carolina library service, I ask for the opportunity to lead.

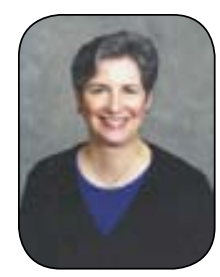

\section{Kathryn Moore Crowe}

Associate Dean for Public Services

University Libraries

University of North Carolina at Greensboro

Greensboro, NC

\section{Education}

BA, History, Randolph-Macon College

MLS, Indiana University

MA, History, University of Georgia

\section{Positions}

Associate Dean for Public Services, University of North Carolina at Greensboro

Head, Reference and Instructional Services, University of North

Carolina at Greensboro

Library Instruction Coordinator, University of North Carolina at

Greensboro

Reference Librarian, University of Georgia

\section{North Carolina Library Association}

Chair, Women's Issues in Libraries Roundtable

Chair, College and University Libraries Section
Founding Chair, Bibliographic Instruction Group

Board member, Library Administration and Management Section

\section{Platform Statement}

I joined NCLA as soon as I moved to North Carolina in 1983 and immediately found it to be a dynamic organization. After 25 years as a member, I still find it vital as an association that promotes libraries and provides professional growth opportunities for librarians and library staff. It has been extremely rewarding to be an active member and serve in a variety of roles. I've especially enjoyed the chance to work with librarians from different types of libraries.

I bring a strong background of leadership in a variety of settings. I have a 30-year career in academic libraries with increasing responsibilities as a manager and administrator. I have held several leadership positions on my campus including chairing university committees and serving as Chair of the Faculty Senate and the Promotion and Tenure Committee. I have served on NCLA's Executive Board twice and therefore have a thorough understanding of how it functions. I have also been active nationally and have been on several ALA committees in RUSA and LLAMA. Through these experiences I have learned how to work collaboratively with others to achieve the goals of the group with which I am affiliated.

Recent difficult economic times have emphasized even more the crucial importance of libraries. The collections and services libraries provide are essential to people from all walks of life. NCLA plays a very important role in keeping the need for strong libraries on the agendas of agencies that support libraries and in promoting libraries. It is also an essential organization in recruiting and nurturing library professionals.

I am honored to be nominated to run for Vice President/President -Elect of NCLA. If elected, I welcome the opportunity to work with librarians and library supporters across the state as an advocate for libraries and librarians.

\section{ALA Councilor}

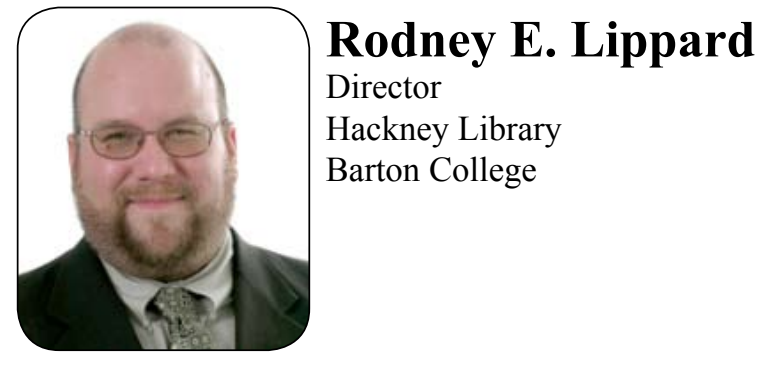

\section{Education}

MLIS, University of North Carolina Greensboro

B.A. in Radio, Television, and Motion Pictures, University of North Carolina at Chapel Hill 


\section{Library Positions}

ILS Workflow Librarian, UNC

Associate Librarian (Collection Development, Acquistions,

Systems), Catawba College

Head of Technical Services/Systems Administrator, Johnson C.

Smith University

Approval Plan Coordinator, UNCC

\section{North Carolina Library Association}

ALA Councilor, 1/2008-6/2009

Leadership Institute Track II Participant, 2008

College and Universities Section

Executive Board Member 1999-2001

Vice-Chair/Chair 2001-2003/2003-2004

Leadership Institute Participant, 2002

Exhibits Chair, 1999 Biennial Conference

Marketing and Publications Committee

\section{Platform Statement}

As the ALA Chapter Councilor, I endeavor to represent all of the libraries of North Carolina to the American Library Association on the floor of Council. As with most everything in North Carolina, our libraries are as diverse as our people, from the large research institutions in the University System to the small public libraries serving rural populations and everything in between; the ALA Chapter Councilor must be aware of the unique needs of every size and type of library and how resolutions made on the floor might have an impact on all these institutions. While my library career has been in academic libraries, during the past year I have begun to think more broadly about libraries and library advocacy. This effort has helped me to more fully recognize the role that all types of libraries play in our communities and in turn how libraries are connected regardless of type.

I was appointed ALA Councilor starting in January 2008 due to the previous councilor resigning because of job relocation. During my brief tenure as councilor, I have become more informed as to how ALA works and the input that councilors have, and I have spoken for North Carolina libraries when needed. I appreciate having this chance and I would welcome the opportunity to build on this information and to continue to represent the libraries of North Carolina. I plan to continue my advocacy efforts and to become more informed about the issues facing all libraries in North Carolina in order to make informed decisions. I hope you will consider me when voting for ALA Chapter Councilor. Thank You!

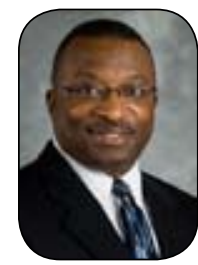

\section{Gerald Holmes}

Reference Librarian and Diversity Coordinator

University Libraries

University of North Carolina at Greensboro

\section{Education}

MSLS, University of North Carolina at Chapel Hill

BS, Criminal Justice, University of North Carolina at Charlotte

\section{Library Positions}

Information Specialist, Library and Information Services, University of North Carolina at Charlotte

Instruction Librarian. Training and Educational Services, University of Cincinnati Libraries

Education Reference Librarian. University Libraries and Media

Services, Kent State University

Reference Librarian. Pullen Library, Georgia State University

Reference Librarian in the Social Sciences. Fenwick Library,

George Mason University

Bibliographic Instruction Librarian. Iris Holt McEwen Library,

Elon College (now Belk Library, Elon University)

\section{North Carolina Library Association}

North Carolina Library Association (NCLA). 1982-1984 and

1997 to present.

Appointed Chair, Placement Center and Recruitment Committee, 1999 NCLA

Biennial Conference Planning Committee. 1997-1999.

Appointed Chair, NCLA Scholarship Committee. 1999-2001.

Roundtable of Ethnic Minority Concerns (REMCo). 1997 to

present.

Elected and served as Co-Director. 1997-1999.

Elected and served as Secretary/Treasurer. 1999-2001.

Elected and served as Vice-Chair/Chair-Elect. 2001-2003.

Holmes, Gerald, Annotated Bibliography, "Ten Best Sports Titles

in My Academic Library", North Carolina Libraries 59:76-77

(Summer 2001).

Holmes, Gerald and Mary Jo Howard, "Today's Graduate, Tomorrow's Leader: Off to a Great Start!", North Carolina Libraries 54:64-67 (Summer 1996).

NCLA-Roundtable for Ethnic Minority Librarians (REMCo)

Roadbuilder's Award in Academic Librarianship, 2005.

\section{Platform Statement}

As a librarian who has worked in North Carolina libraries for most of my adult life, I look forward to every opportunity to advance the mission and purpose of the North Carolina Library Association (NCLA). I have enjoyed every minute I have spent working on numerous NCLA committees and assisting or presenting at various NCLA conferences. I am honored to be nominated to serve as NCLA liaison to the American Library Association (ALA).

If elected, I will bring energy and enthusiasm to my work for NCLA. As our membership grows, so must our efforts to encourage all members to commit time and effort to the Association. Towards that end, I would support and promote the work of NCLA at council meetings during ALA conferences. I would seek opportunities to distribute information about scholarships for students, paraprofessionals, and librarians in a timely fashion; and I would assist in publicizing open positions for students, librarians and paraprofessionals seeking employment. Throughout these efforts, I would welcome and encourage NCLA members to share ideas, participate, and contribute to the organization.

Within ALA, I will promote the work of NCLA and all North Carolina library education programs, libraries, and librarians. I want to be your voice at ALA! 


\section{Secretary}

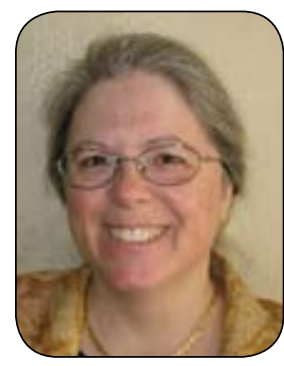

\section{Laura Davidson}

Dean of Library Information Services

Meredith College

3800 Hillsborough Street

Raleigh, NC 27607

\section{Education}

MSLS, University of North Carolina Chapel Hill

BA, English, Wake Forest University

\section{Library / Related Positions}

Head of Information Services, Georgia Southern University, Statesboro, Georgia

Head Librarian, Gwinnett University System Center,

Lawrenceville, Georgia

Information Service Coordinator, Rockingham County Public

Library, Eden, North Carolina

SOLINET Board of Directors, Secretary, 2006-2009

NC-LIVE Training Advisory Committee, 2004-

GALILEO Reference Committee, Chair, 1998-2002

\section{North Carolina Library Association}

College and University Section, Secretary/Treasurer, 2006-2009

\section{Platform Statement}

NCLA is an important venue for fostering collaboration and cooperation among librarians. I believe libraries and librarians are most effective when they cooperate-working beyond their institutional boundaries to create systems and services that benefit their greater communities. NC-LIVE and GALILEO are examples of library cooperation that have vastly extended the capacity and impact of libraries in North Carolina and Georgia. I have worked with both of those projects and have seen the importance of transcending institutional boundaries. The librarians who led those projects came together to work because of connections built through professional associations - not because they were assigned a task by their institution. Professional library associations, particularly at the state level foster the personal connections and create the collaborative environment that makes such projects possible.

I would be honored to participate on the Executive Board. As secretary, I would work to ensure the Association continues to build opportunities for librarians across the state to create a greater community so that we can continue to improve library services for all of North Carolina. I will also be glad to work to manage the records of the Association and minutes of the board, in concert with the Archives Committee.

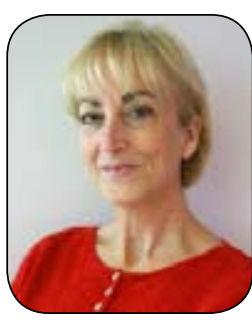

\section{Jody Risacher}

Director

Cumberland County Public Library \& Information Center

Fayetteville, NC

\section{Education}

MLS, Indiana University

B.A., Comparative Literature, Indiana University

\section{Professional Positions}

Director of Cumberland County Public Library \& Information Center since January 1, 2008. Former Deputy Director of said library from 1998 through 2007. Held professional positions in Clermont County Public Library, Ohio, including Youth Services Coordinator and Collection Development Coordinator. Children's Librarian in Kanawha County Public Library, WV

\section{North Carolina Library Association}

Commission on the Future of Libraries, NCLA

Awards Committee, NCLA

Presentation to NCLA Conference: Superior Supervision

(Makes for a Supremely Happy Library). Training based on this presentation was offered statewide through the Branch Services Committee.

North Carolina Public Library Directors Association (NCPLDA). LSTA Advisory Committee

\section{Platform Statement}

It would be an honor to serve on the Board of the North Carolina Library Association. As secretary to the Board, I would eagerly participate and collaborate in upholding the goals of the organization. Through my first year as a new member of NCPLDA, I have been reminded of the value of collaborating with other librarians in order to build a stronger library community. A stronger library community results in a stronger voice in the legislative arena, greater opportunities to utilize the talent of new and existing staff, and most importantly, a better served population of users. NCLA is an integral part of our network of committed individuals. It serves to stimulate the exchange of creative ideas and to strengthen partnerships within and outside of the profession. 
The NCLA membership will be asked to approve two proposed changes to the NCLA Constitution and By-Laws:

1. A change to the constitution and by-laws to create the position of Treasurer-Elect.

2. A change to the constitution and by-laws to define the term of Treasurer as two years.

The proposed changes are below.

\section{OFFICERS}

\section{Treasurer Elect - Election and Term of Office}

Elected by ballot to serve as Treasurer Elect for the first biennium following election and as Treasurer the second biennium. The Treasurer and the Treasurer Elect shall work together during the biennium to ensure an orderly transition.

\section{Duties}

1. To serve as a member of the Executive Board.

2. To serve as a voting member of the Finance Committee.

\section{Treasurer - Election and Term of Office}

Elected by ballot as Treasurer Elect the preceding biennium. Takes office as Treasurer on January 1 following the biennial conference.

The Treasurer completes all financial transactions, including tax returns. The books are audited before the new Treasurer takes office. The Treasurer and the Treasurer Elect shall work together during the biennium to ensure an orderly transition.

\section{Duties}

\section{A. Financial}

1. To be bonded in the amount set by the Executive Board.

2. To serve as a member of the Finance Committee.

3. To pay all bills, manage invested funds, maintain all financial records for the Association, and execute financial procedures established by the Executive Board.

4. To prepare regular financial reports for the Executive Board.

\section{B. Biennial Conference}

1. To work with the Conference Committee treasurer to ensure the proper transfer of funds.

C. Executive Committee

To serve as a member of the Executive Committee.

\section{OTHER CHANGES}

\section{Constitution}

\section{Article V. Officers}

The officers of the Association shall be a President; a Vice President, who shall be the President-Elect; a Secretary; a Treasurer; a Treasurer Elect; and two Directors at Large.

\section{Article VII. Executive Committee}

Section 1. The elected officers of the Association (President, VicePresident/President-Elect, Secretary, Treasurer, Treasurer Elect, and the two Directors) shall constitute the Executive Committee.

\section{By-Laws}

\section{Article I. Elections}

Section 2. Officers. The Committee on Nominations shall present, by November 1 of the year preceding the election, the names of two candidates for each office to be filled: Vice President, Secretary, Treasurer Elect, and two Directors at Large. In case the previously elected Vice President is unable to assume the presidency, the Committee on Nominations shall present the names of two candidates for the office of President.

Section 13. The term of office of all officers except the Treasurer shall commence at the adjournment of the biennial meeting following their election, or if the biennial meeting cannot be held, upon their election. The term of office of the Treasurer shall commence on January 1 following the biennial conference.

(Note: Section 13 currently states that the Treasurer's term of office begins "at the end of the fiscal year following his election." This is not consistent with page 19, where the office of Treasurer is explained in more detail, including the statement that the Treasurer is "Elected by ballot for four years with term beginning the following January 1.’)

\section{Article II. Duties of Officers}

Section 4. Treasurer. ... The term of office shall be two years. In ease of a vaeaney, the Exeeutive Board shall appoint a Treastrer to serve until the next regular eleetion is held.

Section 5. Treasurer Elect. The Treasurer Elect shall work together with the Treasurer during the biennium to ensure an orderly transition. The Treasurer Elect shall serve as a member of the Executive Board and shall serve as a voting member of the Finance Committee. If it becomes necessary for the Treasurer Elect to complete the unexpired term of the Treasurer, the Treasurer Elect shall also serve his or her own term as Treasurer.

[Section 5. Directors at Large becomes Section 6.]

\section{Page 27: Finance Committee}

\section{Membership}

Chairperson (usually someone familiar with the Association budget), the Treasurer of the Association, the Treasurer Elect, plus two or more members, and the President of the Association, ex officio.

\section{Page 101: Frequently Asked Questions}

\section{The NCLA Executive Board}

\section{Who makes up the Executive Board?}

The President, Vice President/President-elect, Secretary, Treasurer, Treasurer Elect, and two Director-at-Large, elected each biennium by the membership of the association. 